\title{
The Tribal Economy
}

\author{
TE MAIRE TAU AND MATTHEW ROUT
}

\begin{abstract}
This essay utilises the concept of the "Māori economy" to explore the story of Māori poverty following colonisation and enrichment after settlement. It merges settler colonisation and institutional economics theories into an analytical framework. Using this framework, it examines the role of settler institutions in Māori impoverishment and makes the case that there is no contemporary Māori economy, arguing a true Māori economy requires culturallymatched political, legal and economic institutions and that without these institutions Māori risk their Treaty settlement funds leaking back into the settler economy.
\end{abstract}

The story of New Zealand's colonisation is often told describing Māori as impoverished due to the sudden and severe loss of land orchestrated by the settler state through fraudulent sales and confiscation. As with many good stories there follows a redemptive arc, where Māori finally regain some of their land and are compensated for their earlier loss, enabling a new "Māori economy" to be established. Much of this is true, making it hard to argue against the general thrust of this narrative. Māori lost large tracts of land, and therefore their capital base, which by the end of the nineteenth century left them destitute. And in recent decades Māori tribes have received "Treaty settlements" and consequently have become increasingly powerful economic players. However, this thrust is only a part of the story, and it produces a narrative hampered by both a focus on "events" and by the influence of dominant tropes. To tell the real story requires two complementary pieces of theory: settler colonialism and institutional economics. Using insights from both, this article will examine the causes of enduring Māori poverty and the fallacy of the contemporary "Māori economy," after which it will outline that the best way for a genuine Māori economy to be brought into fruition in the future would be based on the rūnanga model of the mid-nineteenth century, under which it was proposed that rūnanga had the right to regulate and govern their lands in a manner similar to provincial councils.

\section{Settler Colonialism and its Institutional Structure}

There are two main forms of colonialism, extractive and settler, the latter operating "autonomously in the context of developing colonial discourse and practice." colonialism and its particular discourses and practices that are of interest here. While extractive colonialism is focused on the exploitation of resources, often through the use of indigenous labour, settler colonialism involves the permanent settlement of an area by a group with the aim of creating an enduring regime of control over that area in spite of any previous inhabitation. "Territoriality," as Patrick Wolfe, one of the foremost theorists in this area, explains, "is settler colonialism's specific, irreducible element." If control of land is settler colonialism's endgame, then its means is the elimination of the indigenous inhabitants through either assimilation or genocide. This elimination is justified by an inherently racist "colonial narrative" that frames colonisation as a "modernising" force that either civilises indigenous inhabitants or wipes them out so their lands can be more efficiently utilised. With regard to this elimination, Wolfe incisively notes that "settler colonies were (are) premised on the elimination of the native societies. The split tensing reflects a determinate feature of settler colonisation. The colonisers come to stay-invasion is a structure not an event." 4 And here we come to the first issue with the standard story, that it focuses on events rather than the structure, because

Journal of New Zealand Studies NS27 (2018), 92-109 
both the efforts at elimination and goal of domination are not transitory but rather endure.

Many attempts to understand the impacts and consequences of settler colonisation are limited by this events-centric focus. ${ }^{5}$ Rather than examining the widespread and enduring nature of settler colonisation as a structure, there has been a focus on the most bloody and dramatic events in colonial history. Possibly the desire to focus on colonisation as an event stems from confusion between and conflation of extractive and settler colonialism, where the former is more of a series of traumatic events while the latter is very much an enduring structural change. Whatever the cause, settler colonisation is unmistakably permanent; it "establishes western law within a white supremacist political economy premised upon the perpetual elimination of Indigenous peoples." Mention of law and political economy - the permanent "structures" of settler colonialism - brings us to the next crucial piece of theory: institutional economics.

The neoclassical school has long been the paradigmatic conception of economics despite what many would note is an overemphasis on human rationality and the consequent sole focus on "the market." As Mark Granovetter notes, "neoclassical economics operates . . . with an atomized, undersocialized conception of human action." "It assumes that every human is, in Thorstein Veblen's memorable phrasing, "a lightning calculator of pleasures and pains," thus creating "a world of self-interested but law abiding and social responsible individuals who choose freely between competing alternatives on the basis of perfect information." While reducing "economics" in this way has enabled the field to become largely quantified, and may even have some degree of fidelity with economies that have already undergone Karl Polanyi's "Great Transformation" to a competitive "market society", it is essentially useless for studying the economics of settler colonies, particularly from an indigenous perspective. It is a trope that hinders rather than helps understand the reality behind the story. ${ }^{10}$

Institutional economics provides a far more insightful means of understanding Māori impoverishment and the problems with the term "Māori economy." As the title indicates, institutional economics emphasises the role that institutions play in economics, where institutions "are the rules of the game in a society or, more formally, are the humanly devised constraints that ... structure incentives in human exchange, whether political, social, or economic." 11 While the neoclassical school believes that institutions develop to meet a society's economic needs in a logical manner, institutional economics understands that institutions are not controlled by a rational market - that rather that it is the nature of the institutions that structure economic opportunities. ${ }^{12}$

Institutions are generally described as being either formal or informal, with the former being written and/or issued by a relevant authority and the latter unwritten and/or socially constituted. ${ }^{13}$ However, it is more useful to think of them as a continuum. At one end are the most highly prescriptive, detailed, and specific written rules that a society may codify, while at the other-beyond even the informal institutions themselves - is the underlying general worldview of a society, the base framework through which its members understand reality and which informs their culture and all of their institutions. Oliver Williamson identifies four levels of institutions: the highest is social embeddedness, essentially a society's informal traditions, norms, taboos etc.; the next level down is the "formal rules of the game," namely laws; the third level is the "play of the game," including contracts and property titles; and finally the bottom level is the market itself, the sole level neoclassical economics examines. ${ }^{14}$ Each higher level imposes "constraints" on the lower levels, while "feedback" flows from lower levels up. Paul Joskow believes these levels can be broadly generalised as covering, from highest to 
lowest, social, political, legal, and economic institutions, which while not entirely accurate is an insightful division. ${ }^{15}$

Fusing the formal/informal continuum with Williamson's levels provides a useful institutional topography, with the largely subconscious worldview as the most influential shaper, from which emerge increasingly specific and codified constraints across the political, legal and economic domains, which are somewhat hierarchical in their relations but, depending on the worldview and peculiarities of the society, could display a range of different interactions. While some of the most salient dynamics of Māori and Western institutional interactions will be mapped out below, suffice to say here that one core difference is that in the former the economic can be seen as firmly embedded within - and thus constrained by - the higher institutional layers, while the latter has seen a progressive "dis-embedding" of the economic from the cultural, political, and legal, with a major consequence being that economic exchange has become less constrained by society.

Settler colonialism involves the permanent replacement of indigenous institutions with settler institutions within a territory. As E.A. Brett writes, colonisation was "a radical force for institutional change" that "marginalized indigenous structures and excluded local people from the management or regulation of the new ones." 16 These institutions cover virtually every aspect of indigenous life, from the sociocultural to the political, from the legal to the economic. For indigenous inhabitants, settler colonisation is the loss of not just land but the institutional autonomy that control of territory provides. It is through institutions that settlers maintain control; such institutions are designed to function as a means of domination, meaning they are not only structurally biased towards the settler but they endure. Both land loss and settlements can be understood as "events" or, viewed through the neoclassical economics lens, as exchanges. However, these exchanges did not take place within a vacuum but rather were constrained by the settler state's enduring institutional framework. Therefore, these more visible exchanges should not be viewed in isolation but rather must be contextualised by the enveloping structure of settler institutions within which indigenous peoples must operate. From this we can began to unravel the truth behind the story, first regarding land loss and poverty, then exploring the reality of the so-called "Māori economy," before drawing lessons from both for the future.

\section{The Role of Institutions in Māori Impoverishment after Land Loss}

Before contact, Māori controlled the roughly 60 million acres of New Zealand; yet by 1911 they held just 7 million acres. Still, as Richard Boast tells us, only a few million acres had been confiscated by the Crown. The majority of land was purchased through transactions, which Stuart Banner notes occurred "with all the formalities of real estate sales back in England"; nevertheless, the outcome was that Māori became nearly as poor and marginalised as Australian Aboriginals or North American Indians. ${ }^{17}$ Furthermore, Banner supposes that Māori would have fared little worse if they had had their land confiscated. He then asks a profound question, "How could the Maori have sold so much land and ended up so poor?"18

After rebutting the standard responses of blaming either the Māori sellers or the British buyer for ignorance or avarice, respectively, Banner then answers his own question, explaining that Māori were "conquered by contract"-a conquest facilitated by Māori belief that the market was subject to natural laws, viz. that it was "free." Māori believed land sales with Europeans would be governed by supply and demand. As Banner incisively points out, however, markets are not "distributionally neutral," but rather are human constructs and the New Zealand 
institutional structure was designed by the British Empire to facilitate the alienation of land from Māori to the empire. ${ }^{19}$ The great irony is that Māori, like Adam Smith, believed in the "invisible hand" of the market. Māori, Banner argues, failed to understand that the market was not designed for them to hold their land, nor to prosper. Rather the settler government chose to create a particular economy and therefore constructed a politico-legal edifice within which Māori had to operate. Banner concludes by saying that:

Patterns of landholding and wealth allocation might look very different in New Zealand today. The choices made as to how the market would be constructed hurt the Maori more than the actions of any single person operating within it, and maybe even more than the actions of all the people operating within it, although there is no way to know for sure. In not thinking clearly about markets, we can miss seeing this. ${ }^{20}$

Banner's warning about not seeing the market needs to be expanded to its full parameters, for it is the entire institutional structure of the settler state rather than just "the market" that needs to be seen. Initially, Māori could not see the construction of the institutional edifice that would eventually come to dominate them politically, legally and, with particular relevance here, economically.

With respect to Ngāi Tahu, the examples below will help illustrate how this edifice functioned, as well as providing a possible blueprint for a future Māori economy. First, in 1860, twelve years after Ngāi Tahu had sold 20,000,000 acres of land for £2,000, the Port Levy Ngāi Tahu, now living on a small reserve, were asking Governor Thomas Gore Browne for a loan to assist them in the erection of a flour mill and instruction on its use:

Friend, hearken!

We are striving to adopt the example of the Pakeha. As an instance of this, we seek your approval of the erection of a flour mill at Port Levy; and we ask for your assistance in the same manner that you have aided the people of the Northern Island in the construction of their mills; and further, that you will send us a wiseman (a millwright) to superintend the work, that it may be properly done. All the machinery has arrived and we have paid for it the sum of $£ 38015 \mathrm{~s}$. $3 \mathrm{~d}$. The assistance we ask of you is to erect the house, to put up the mill, and to dig an aqueduct. And when the proceeds of the mill are sufficient, we will repay your advance. Let this be made a proof of your regard for us. $^{21}$

Far from being poverty stricken, the Port Levy Ngāi Tahu were asking for an "advance" or a bank loan to expand their operations. As the request shows, they had already purchased the machinery. What they needed was technical instruction in using it and placing it inside a mill house. Once their profits came through, they would repay the advance. If they had been impoverished by the loss of land over a decade earlier it is unlikely they would have been in such a position. Further showing how it is the institutional framework that counts with regard to economic outcomes, Port Levy Ngāi Tahu had also asked Governor Browne to confirm their individual titles that Walter Buller had been working on the year before at Kaiapoi and their own village. Each whanau had its own fields of wheat, but would gather as a community to thrash and mill the flour. Here we see the traditional socio-political institutions (mapped out by scholars such as Hazel Petrie) which created a balance between self-interest and communal good, facilitating a thriving and resilient industry even after significant land loss. Port Levy Ngāi Tahu were prospering because within the limited Crown institutional framework of the time, such communities had a degree of autonomy that enabled them to structure their economic actions in ways that suited them both socially and economically. ${ }^{22}$ As an illuminating 
postscript to this, Petrie notes that the loan was declined, and the mill never built. This was because, she surmises, their "inability to offer land for sale had left them with little bargaining power and their smaller population offered a less daunting threat in terms of rebellion." ${ }^{23}$ While this may suggest that land loss was the crucial impoverishing factor, the most important factor is institutional control. Because Port Levy Ngāi Tahu did not represent a threat to the Crown's grab for substantive sovereignty, the Crown did not need to offer them credit. Land sales were the means to the ends of substantive sovereignty.

The second example shows how the settler institutions structurally disadvantaged Māori. Poutini Ngāi Tahu set aside significant reserves on the West Coast, the most important being 500 acres which became known as the Mawhera Reserve, located at the mouth of the Grey River. Greymouth township was soon established and eventually spilled over onto the Mawhera Reserve after the West Coast goldrush accelerated in 1865. Inevitably, the reserve gained considerable commercial value. Merchants leased much of the reserve from the tribe with the leases running for three years. In a sense, the relationship between the settlers and Māori was purely commercial, wherein the invisible hand of the market followed supply and demand. What followed next was the open hand of the government, who intervened in this largely satisfactory arrangement. The reason given was that that it wanted to ensure that the leases were "formal" between both parties so that trouble would not arise, when really the institutional structures were manipulated to benefit the settlers - that harmonious marriage soon favouring settler profit. As soon as the reserves became valuable, the politico-legal institutions were restructured and the reserves were placed under the 1856 Native Reserves Act, which meant that they fell under the trusteeship of the Governor. Consequently, Māori lost institutional control of their land and the settlers got low rentals. Māori did not even have control over the revenue, as it fell under the Governor's direction - and much of the revenue was ploughed back into the development of the town. In fact, between 1865 and 1875, 20 percent of the rental was paid towards rates, street repairs and other improvements. ${ }^{24}$

The leases were also extended to fourteen and then to twenty-one years. When the land fell under the trusteeship of the Crown it became subject to political lobbying from the settlers who, fuelled partly by the racist colonial narrative, detested the idea of Māori landlords and wanted the land at a low rent for a perpetual lease or to have the right to buy it. In 1887, Parliament passed The Westland and Nelson Native Reserves Act, which essentially granted the leaseholder a perpetual right of renewal every twenty-one years for an indefinite period, with the owners having the right to renew the rent on every lease renewal. However, the owners had essentially been removed from having the right of management, occupation, control or use. As the Crown itself acknowledged, it had "effectively transferred the entire domain of the lands to the lessee." 25 The rents that were set were very low: because the land was essentially owned by the leaseholders, no outside competition could be used to assess its value. The full weight of the settler institutional structure had been used to disadvantage Poutini Ngāi Tahu.

This is a perfect example of Banner's point. The amount of land allocated to Māori in the circumstances just explained was a secondary matter. The value of the land was itself considerable, and in any normal situation Māori should have been in a prime position as landlord. However, the law was used to weight the market in favour of the settlers. Māori were excluded from operating in the same economy. And it was the economy that the Poutini Ngāi Tahu wanted to operate within, which is why they agreed to the nominal sum of $£ 300$ for the West Coast Purchase. The lesson to be learnt from the West Coast Ngāi Tahu experience is that the institutional structure was framed for the settlers because they had effectively removed 
the capacity of the Ngāi Tahu landowners to act in-rūnanga or in-council in the same way that settler councils or provincial governments could act. The right of the Ngāi Tahu landowners to govern and regulate their lands was removed from their rūnanga and placed in the hands of the Governor, who governed by way of the 1856 Native Reserves Act.

These examples beg the question, why were Māori unable to see the impending institutional edifice that would impoverish them? One answer to this is that pre-contact Māori institutions were starkly different. While the pre-contact Māori economy had involved a mixture of socially-constrained reciprocal and pragmatically-oriented barter exchanges- the latter enabling them to be judged as astute traders by explorer James Cook during his visits - their institutions placed limits on potential individual avarice as kinship obligations meant that wealth could not be individually accumulated. ${ }^{26}$ Another way of framing this is to say that the pre-contact Māori economy was more constrained by the higher level institutions than the British economy, which had already undergone Polanyi's "Great Transformation," in that the purpose of the majority of exchange was as much kin bonding through ongoing ties of reciprocal social obligation as it was the interchange of goods and services, and the exchanges were governed by a strict and intricate lore that was intimately informed and enforced by Māori spirituality. ${ }^{27}$ In the British economy, on the other hand, as Polanyi explains with regard to the market economy:

Instead of economy being embedded in social relations, social relations are embedded in the economic system. The vital importance of the economic factor to the existence of society precludes any other result. For once the economic system is organized in separate institutions, based on specific motives and conferring a special status, society must be shaped in such a manner as to allow that system to function according to its own laws. ${ }^{28}$

The consequence of this dis-embedding is that "all social considerations, motivations, and values take a back seat to the empirically acquired primacy of the economy, which becomes autonomous from all (conscious) social control." ${ }^{29}$ In other words, Māori not only faced an institutional edifice that was structured against them but that was largely unconstrained by the values trumpeted by the settlers when justifying colonisation as a positive "modernising" force. Take the British value of "justice," a core component of the colonial narrative: as Māori would discover time and time again at the Native Land Court - the "veritable engine of destruction for any tribe's tenure of land, anywhere," as Hugh Kawharu described it-justice was nothing against settler avarice. ${ }^{30}$ Rather than upholding the principles of British justice, as the Waitangi Tribunal found, the Land Court "was a wrongful imposition, promoting individual caprice and judges' preference." 31 In short, it was unjust.

This institutional bias means that even if Māori had been allocated more land, the end point would likely have been the same: they would still have been an impoverished people because the institutions were calibrated to benefit the settler and the British Empire as opposed to Māori. Specifically, the market and its supporting institutions were fundamentally a product of capitalism's insatiable need for growth mixed with the self-aggrandising drive of imperialism, as exemplified by the conversion of land into property. As Polanyi wrote:

What we call land is an element of nature inextricably interwoven with man's institutions. To isolate it and form a market for it was perhaps the weirdest of all the undertakings of our ancestors. ... And yet to separate land from man and to organize society in such a way as to satisfy the requirements of a real estate market was a vital part of the Utopian concept of a market economy. Again, it is in the field of modern 
colonization that the true significance of such a venture becomes manifest ... [as] in any and every case the social and cultural system of native life must be first shattered. ${ }^{32}$

Colonisation was an unavoidable outcome of imperialist capitalism. The institutions within which Māori found themselves operating were not only alien but were structured so as to alienate them from their resources. Thus, the settler government constantly manipulated the market, property titles and other institutions to ensure ongoing acquisition and retention of land and the general transfer of resources from Māori to the settlers. New Zealand history is replete with examples of this institutional manipulation, with the ever-changing nature of Māori property title as possibly the most egregious example. ${ }^{33}$

It was only as the institutional structure of the settler state became entrenched that Māori were impoverished. Governor Browne estimated that Māori brought in $£ 51,000$ in customs revenue in 1856 , as compared to the settler economy which contributed $£ 36,000 .{ }^{34}$ As a number of scholars have noted, the early decades of settlement were characterised by Māori economic dominance, with their quick and widespread adoption of western agricultural and production practices seeing Māori growing enough crops and manufacturing enough flour, often milled in one of dozens if not hundreds of their own mills, to trade nationally and export internationally, often in one of their many coastal and international trading vessels. ${ }^{35}$ The nascent colony needed Māori supplies to survive. Thus, as well as fulfilling the justifying component of settler colonisation, there was a pragmatic logic behind encouraging Māori industriousness. In this, we see settler colonisation's drive for profit and its modernising justification married in relative harmony. However, when they came into conflict, settler profit nearly always trumped Māori outcomes. For at its core, settler colonisation is premised on a paradox, driven by imperialistic capitalism but justified as modernising for those indigenous inhabitants not slated as being "too primitive." 36 It is no coincidence that between the 1860s and the 1880s, as the demographic balance shifted in favour of the settlers and the "state's coercive machinery gradually but inexorably turned nominal sovereignty into substantive sovereignty," the golden age of the Māori economy came to an end. ${ }^{37}$ Certainly, this was also the period that saw huge land alienation; but rather than being the direct cause of impoverishment, we argue, the alienation of land facilitated the institutional domination, which caused Māori economic fortunes to change. Before being subsumed by the settler institutional framework, Māori thrived under their own institutional structures; but as settler political authority, driven by land alienation, blanketed the country, Māori prosperity declined.

\section{Rūnanga as an Historical Institution}

History often contains enticing alternatives, moments when different forks could have led to different outcomes. In the story of the colonisation of New Zealand, one of these was the proposed rūnanga system of the late 1850s and early 1860s. This apparent alternative history, however, is more complex than the narrative indicates. Certainly, by today's standards it provides an empowered alternative to the current situation; however, it must be considered in the context of its specific time period.

In 1858, Parliament had passed the Native Circuit Courts and the Native Districts Regulation Acts, both of which were designed to give village rūnanga the capacity to regulate their own affairs and economic activities upon those of their lands that were still in "customary title." Three years later, new Governor George Grey, Premier William Fox, and Attorney General Henry Sewell were all advancing the idea of rūnanga as self-governing bodies for Māori. 
Essentially, rūnanga were meant to have been similar to provincial councils, including the right to regulate and govern their lands. Grey pressed ahead with his concept for rūnanga system, the "New Institutions", a variation of the earlier legislation. ${ }^{38}$ The motivations behind the 1861 scheme were mixed, and heavy constraints were to be placed upon those rūnanga authorised by the Crown. ${ }^{39}$ But the possibilities for Māori were quite breath-taking when viewed from the contemporary perspective.

The challenge for us is that to understand what the rūnanga were meant to be, we have to remove from our minds the Native Land Court, and we must place ourselves in what was a watershed period where the flux of institutional control was at its most intense. Otherwise, we fall prey to the alternative history narrative. The rūnanga scheme was tied to land and while the Native Land Court dominates our understanding of Māori land in the nineteenth century, it is also a distraction because the key period of Māori economic growth occurred in the years that quietly sit before the Native Land Court, when Māori still retained their land outside of Crown title. The tendency is to say that this land was "customary title," but this term is misleading as it automatically lends itself to didactic thinking, equating the term to ideas such as non-commercial economies, communal title and usufruct rights with no sense of property or individual title. These notions are western ideals imposed upon Māori, which served to justify alienation of Māori land as it was not being used "efficiently" in the Lockean sense; that is, in the sense that property is acquired through the exertion of labour-specifically western style agriculture. This portrayal of indigenous peoples as living in a state of nature where land was commonly owned and uncultivated, often derided as "primitive communism," was part of the discursive strategy used by settler governments around the world to justify the expropriation of land. It can be found in Sewell's explanation that the "object of the Native Land Act [1865] was ... to destroy if possible, the principle of communism which ran through the whole of their institutions." 40 Yet we know that before the Native Land Court, Māori made commercial use of their land; that they did have a mixture of individual lands as well as communal areas, that they had a developed understanding of property and that there was probably no real equivalent to a usufruct right. The problem is that when we talk about customary title, we are really making a series of speculations and assumptions about what we think "property rights" were before settlement. In making these guesses, we are really ignoring the customs that we know Māori were practicing upon the land just before Crown title was imposed by the Native Land Court. That is, we ignore the actual use of land practices between the 1830s and the 1860s.

Rather than use the term "customary title," it may be better to view Māori land before the land was converted to Crown title as "extralegal tribal title" - tribal land beyond the law, with the qualification that within the tribe, custom was the law, consuetudo pro lege servatur. These terms take into account the fact that Māori were capable of developing their own laws and customs upon their land, laws and customs that were both rooted in tradition but also dynamic enough to evolve with the commercial and economic changes that were being imposed on the lands surrounding them. Custom should not be taken to imply an unchanging tradition, which Māori society was not. This static view of Māori was promulgated by colonial narrative as it served as a powerful contrast to the "progressive" and "industrious" settler, and it helps explain why politicians and state officials had little grasp of how Māori managed and ordered their land. In a cross-examination during the 1860 investigation into native tenure, Donald McLean, who had considerable experience and knowledge in the area, felt unable to give any definitive statement about Māori land tenure other than it varied among the tribes and that the exception was the rule. ${ }^{41}$ McLean's understanding is insightful because what it meant was that for any development to occur, it would have to take a case-by-case approach. This is exactly the 
approach that was taken with the proposed rūnanga system before the Native Land Court applied its monolithic declarations of what customary title was. One of the most fascinating discussions on the Native Land Act of 1862 is the debate during its time as a Bill in parliament. In particular, James Edward FitzGerald, the member for Ellesmere, made the following observation:

He hoped that the Government would have extended their runanga system. The Native Lands might then bear the same relation to the runangas as the waste lands of the Crown did to the Provincial Government - that was, if they wanted to sell or lease the land, it would be for the runanga of the district to make regulations for it. The district runanga had been told that it should have the disposal of the lands; what, then, was the use of bringing down a Bill saying that this Court should have the power? ${ }^{42}$

This passage is critical to our understanding of the New Institutions. They were to have selfgoverning powers over their lands, which allowed them to make regulations and to decide the terms of sale, lease and other forms of disposal. That is, they would convert their customs into some kind of regulatory framework. If we read further, it is also implied that the rūnanga had jurisdiction over a kind of title-why else would FitzGerald question the role of the Native Land Court? He correctly asked the House why it needed to establish a Native Land Court when rūnanga had already been allocated the role of administering land and determining its title under the Native Circuit Courts and the Native Districts Regulations Acts of 1858. FitzGerald believed that, with appropriate enabling legislation already in place, the powers of the rūnanga could be extended to have the same capacity as that of the provincial government over land sales. The matter of determining native title was of little use to him because the only issue for the Crown or the settler was when "the native" wanted to sell. Once that decision was made, it was for the rūnanga to decide whether or not the sale could be confirmed. The absolute simplicity and brevity in his reasoning is stunning. When we consider the horror that the Native Land Court-Kawharu's "engine of destruction"-was to bring upon Māori land, we should keep FitzGerald's question to the forefront. If land would be regulated by rūnanga under their own title the disastrous loss of land that came in the wake of the Native Land Court's operations might have been avoided.

Under the New Institutions, then, the focus was on allowing land to be purchased from Māori, but with the proviso that rūnanga be the mechanism for the transaction. Grey, like Browne before him, was of course responding to the settler drive for land, but he was also aware that a wholesale approach to land purchases would cause problems with Māori. To this end, the Crown needed to manage the situation carefully. Grey's stated intention was to breathe life into the rūnanga system already in operation so that a rūnanga's jurisdiction would be "co-extensive with the lands of the hapu or hapus of which it consists." ${ }^{43}$ It should be noted that the stated intentions and their real motivations were not necessarily the same, however. As Sinclair put it, Grey was "obliged to face two ways," while O'Malley - in line with Hill - more specifically claims that there was "never any intention of allowing the runanga (tribal councils or assemblies) established under this system to develop into state-sanctioned instruments of genuine self-government". He argues that rūnanga were a way for the Crown to turn its nominal sovereignty into a more substantive form by acting as a vehicle for settler institutional penetration. ${ }^{44}$ As a select committee in 1860 stated, "properly organized and placed under the control of Government, . . . the Runanga would become a great instrument of civilization, a powerful means of securing order, and a machinery for facilitating the administration and disseminating the principles of law." 45 It is unsurprising, then, that rūnanga "were quickly abandoned by the Crown when they proved to be no longer useful as institutions of socio-racial 
control of Maori. ${ }^{\prime 46}$ Thus, in reading this history, we must remember the paradox at the core of settler colonisation that made the rūnanga plan "two-faced." Here we will examine the publicly-stated institutional framework, with the caveat that more lurks beneath the surface.

As presented, rūnanga would not only have been the administrative vehicle for the hapu but also were to have some kind of jurisdiction over the land. Grey outlined how he saw the process:

So soon as the boundaries and ownership of any lands in any District have been ascertained and defined, in accordance with the regulations of the Runanga, and have been registered in the Civil Commissioner's office and approved by the Government, the Native owners will be permitted to dispose of any such lands, or part of such lands . . . by direct sale to any purchaser who may be approved of by the Government on the recommendation of the Runanga. ${ }^{47}$

Grey and his ministers saw the role of the rūnanga as the "strategic point." Fox took special care to caution Grey that in regards to the role of Māori as vendor the need was "to leave the matter substantially in the hands of the Runangas." ${ }^{48}$ However, Fox also saw them as a way of enfolding Māori into the wider settler institutional framework, as he explained:

We look to the runanga, or Native council, as the point d'appui [strategic point] to which to attach the machinery of self-government, and by which to connect them with our own institutions. ... We have no choice but to use it, it exists as a fact, it is part of the very existence of the Maori-we can nor more put it down than we can stay the advancing waves of the rising tide; and, if we do not use it for good purposes, it will assuredly be used against us for bad. ${ }^{49}$

The danger of alternative history is judging the past by today's standards. What today looks like a radical autonomy for Māori was then a way for the settler state to gain greater institutional control. This is where historical context is key: at the time, Māori were largely outside the settler institutional structure, and rūnanga were seen as a way of gaining greater control over them.

Grey and his Ministers were committed to resolving serious problems, of which the most obvious was the rising tension over land sales, although the more insidious was the failure of settler institutions to penetrate and constrain Māori life. Their motives were, unsurprisingly, mixed. Grey had been given a mandate to bring the growing land crisis under control, and was a noted proponent of "radical assimilation," yet was also more engaged with Māori culture than most of his contemporaries-He neatly embodied the paradox at the core of settler colonialism. ${ }^{50}$ Sewell, in particular, often invoked the Treaty of Waitangi. For him the Treaty was important for two reasons. First, it allowed settlers to purchase land from Māori. Secondly, the Treaty allowed Māori their right to self-government. Today we see these terms as incompatible. But this was not the case in the nineteenth century; they form the very core of the settler paradox. When Sewell spoke of bringing the bulk of Māori land within the reach of colonisation and the right of Māori to self-government, he saw no contradiction. For Sewell both views aligned with the Treaty of Waitangi. In 1864 Sewell would write to Lord Lyttelton:

The Treaty of Waitangi expressly reserves to them their territorial rights. As to the former, it is true they surrendered to the Queen the "Kawanatanga"- the governorship-or sovereignty; but they did not understand that they thereby surrendered the right of self-government over their internal affairs, a right which we never have claimed or exercised, and could not in fact exercise. ${ }^{51}$ 
Furthermore he was of the opinion that the idea of self-government-by which he meant limited tribal government akin to that of the provincial government — was not an unusual affair but was simply an accepted part of imperial policy. ${ }^{52}$ In his letter to Lyttelton he outlined the judicial position of the United States to Native Americans: until their title had been extinguished they should be considered "denominated domestic dependent nations." 53 Sewell then turned to a dispatch from the Secretary of State for the Colonies, Lord Stanley, to Governor Robert FitzRoy in 1841, wherein Stanley argued:

I know of no theoretical or practical difficulty in the maintenance under the same sovereign of various codes of law for the government of different races of men. In British India, in Ceylon, at the Cape of Good Hope, and in Canada, the aboriginal and the European inhabitants live together on these terms. Native laws and native customs, when not abhorrent from the universal and permanent laws of God, are respected by English legislatures and by English courts; and although problems of much difficulty will occasionally arise out of this state of things, they have never been such as to refuse all solution, or as to drive the local authorities on the far more embarrassing difficulty of extending the law of England to persons wholly ignorant of our language, manners and religion. ${ }^{54}$

Much of the groundwork for the rūnanga system had already been laid during the period of Governor Browne, who initiated the 1858 legislation enabling a degree of self-regulation for rūnanga. The Native Districts Regulation Act allowed the rūnanga regulations to supersede laws of the provincial councils. And despite the fact that most of the regulations were concerned with cattle, fencing and dog control, a closer reading would suggest that most modern tribal corporations would be amazed at the latitude for development provided under the Act. Regulation II (7), for example, allowed the rūnanga to have powers:

for ascertaining, prescribing, and providing for the observance and enforcement of the rights, duties, and liabilities, amongst themselves, of Tribes, Communities, or Individuals of the Native Race, in relation to the use, occupation, and receipt of the Profits of Lands and Hereditaments.

In short, this clause gave the rūnanga the capacity to regulate, manage and administer the lands within its district. Moreover, and this is the point that FitzGerald was making, the regulations were to supersede the laws of the provincial council. ${ }^{55}$ This is the kernel of the idea of a selfregulating tribal economy upon lands that remained under tribal authority and regulation. What this tells us is that neither party saw customary land as non-commercial. It was simply extralegal-beyond the reach of the Crown. The idea of self-government and of a rūnanga overseeing the administration of the land was exactly the opposite of what the settlers wantedthe individualisation of title so as to allow direct purchase between Māori and the settlers. ${ }^{56}$ From the settler point of view, both Crown policies and the rūnanga were obstructions to land alienation that needed to be removed. The Crown, however, was playing the long game, realising that if the land alienation was to be successful then it needed institutional dominance.

Despite the intentions behind the rūnanga scheme, however, the proposed institutional framework was and remains striking: what was then intended as a tool of subjugation could now, over 150 years later, be the blueprint for increased institutional autonomy for Māori. Such are the vicissitudes of colonisation. There is, moreover, continuity with that distant past. While the Crown's interest in rūnanga quickly faded as it favoured more extreme institutional mechanisms of alienation, Māori had continued to utilise them in a variety of forms. Since the 
modern settlements with the Crown under the Treaty of Waitangi, rūnanga have taken on new and increasingly powerful roles. In 1990, the Runanga Iwi Bill was passed, enabling legally incorporating rūnanga to be the administrative wings of the tribes, though they lacked the full extent of the powers proposed in the 1860s. Although the Act was quickly repealed by an incoming National government, such rūnanga continued and other legal entities were also later established to run iwi affairs following Treaty settlements. ${ }^{57}$ Such institutions could be the seed from which a Māori economy grows, though clearly the post-1990 rūnanga would need to be given far greater powers than they currently have. Only then could there truly be a "Māori economy." For the story to come full circle, then, we believe that the rūnanga model proposed back in the nineteenth century needs to be reinvigorated, but before exploring this further we need to examine the contemporary claims of a "Māori economy."

\section{A Māori Economy?}

The term "Māori economy" has been increasingly common in recent years, following the raft of Waitangi Tribunal settlements. It can be found in government documents, press releases, newspaper articles and academic works. This article takes the view that despite the numerous claims that there exists a Māori economy, which in 2017 was supposed to be worth an estimated $\$ 50$ billion, Māori have yet to create an economy that they could say is truly theirs. ${ }^{58}$ The $\$ 50$ billion that we are led to believe constitutes the Māori economy exists in the same fashion as the Mawhera rents - it falls within the wider Pākehā economy. Likewise, despite the economic growth of tribal corporations, we do not have a tribal economy because such corporations are essentially an adjunct of the national economy. After all, the prime asset of tribal corporate bodies-land - is vested in the Crown, rather than under "tribal title" as before colonisation. And, just as the land falls under Crown title, the market in which the land and other assets are regulated also fall under Crown law and regulations - all of which must imply a nation state economy.

There are, of course, a number of ways the term Māori economy could be defined, from a farreaching institutional economics-oriented delineation that includes law-making, taxation capacity, contract enforcement and the like, through to a more tightly neoclassical synthesisfocused demarcation using leakage. In macroeconomics, part of the synthesis, the circular flow of income-flows of money, goods, services and the like between economic agents - forms the model of an economy, and leakage is the loss of funds from that economy's circular flow through an exchange, say from a national economy via international trade. Even defined neoclassically, "Māori economy" is highly problematic, as tribal businesses usually experience leakage in the first exchange, with virtually all money returning to the wider settler economy. Furthermore, given the socially-embedded nature of the pre-contact Māori economy, the institutional definition is considered a more appropriate gauge. Measured by this, the term Māori economy is totally inaccurate, as Māori tribal businesses still have to operate within settler institutions. Certainly, many of the more biased institutions have been removed or ameliorated, but the overarching institutional structure remains settler in form. A true Māori economy would be one that not only delivered the multiplier effect but was also conducted within a Māori-oriented and Māori-operated institutional structure.

Just as the enduring poverty following land loss can be traced back to ongoing institutional dominance, so too can the falsity of claims for a present day Māori economy. To expect Māori to have developed an economy for their own well-being in the absence of any governing capacity or institutions to enforce and regulate their lands and properties is to show a remarkable lack of insight into how an economy functions and how a Māori economy has not 
functioned. Because we lack the most fundamental of any of the above institutions, our problem is that whenever we talk about a Māori economy we simply cannot explain what it looks like. Māori land does not sit within a governance structure that is uniquely Māori for the simple reason that until recently all Māori land fell under Crown title and therefore Crown governance. Māori have no institutional capacity to raise land tax (rates) off the land, and tribal corporations all function under Crown legislation. There simply is no Māori economy other than what functions within the existing settler economy.

In fact, the central components that underpin the settler economy-its laws, regulations, institutions and property rights - are designed to maintain the dominance of the settler state. The institutional framework is calibrated to undermine any attempts at an economy that is Māori. It could be argued that this is simply a fact of a modern economy, yet there are contemporary examples that show this not to be true. Even in the United Kingdom, there are self-governing dependencies with their own economies and commercial arrangements with the Crown. The legal system in the dependency of Guernsey, for example, is a derivative of Norman French customary law, but it has also been overlaid by English common law.

No tribal organisation exists in Aotearoa today with any capacity to tax, nor the right to establish any local bylaw or regulation over its land. Economies exist when supporting institutions are created with the power to regulate property and to tax. This fact quite bluntly challenges anything the Crown has considered for Māori in the era of Treaty settlements, and it also challenges the modern orthodoxy of what constitutes a Māori economy. Despite all the settlements that have occurred over the last two decades or so, none have anywhere near approached the self-government possibilities of the short-lived New Institutions policy, showing both how different the power dynamics of today are to this period and how the settler mindset has shifted. Despite advances in the past decades, there is no Māori economy from either a neoclassical synthesis or institutional economics perspective.

Looking at post-settlement Ngāi Tahu, specifically Te Rūnanga o Ngāi Tahu (TRONT), we can see what this means in a real sense. The Wigram Skies development is an interesting example. Ngāi Tahu Properties took most of the risk in the venture, yet roughly 80 percent of the total profit of nearly $\$ 1$ billion leaked. While some of that would have been difficult to retain within the tribe even if it did have greater institutional control-such as the third of that 80 percent profit retained by building materials manufacturers and retailers-other areas, including the roughly 17 percent of that 80 percent that the Crown made through tax revenue from the Goods and Services Tax (GST), could have been retained if had the tribe possessed institutional control. ${ }^{59}$

In the process of developing residential sections in the Wigram Skies development, Ngāi Tahu created a whole new economic infrastructure, such as sewerage, water mains and roading, that automatically rolled over into the ownership of the Christchurch City Council. And on top of this, the council gained the rates, which from 2010 to 2016 amounted to roughly $\$ 186$ million. ${ }^{60}$ As well as the residential properties, Ngāi Tahu created a settler commercial district to function within the settler economy, providing economic opportunities through new zoning consents for businesses to operate. Economists call this a "virtuous circle of investment," wherein the community benefits as a whole. However, because no similar directed investment is made into Ngāi Tahu communities, there was no benefit to the Ngāi Tahu community other than the immediate profit. 
It could be countered that the leakage experienced by Ngāi Tahu Properties is mitigated or balanced by TRONT's own virtuous circle. A Holdings Corporation was specifically set up to generate capital for TRONT, which then uses this to fund wider social, cultural, developmental and educational programmes for the benefit of the tribe. However, this corporate-beneficiary model, where the core economic component has been severed from the members of the wider tribe, who then become dependent beneficiaries rather than active participants, is itself a settler construct. ${ }^{61}$ This is further emphasised by the disconnect between Ngāi Tahu Propertieswhich does not have a mandate to focus on maximising employment of tribal members, and so left the construction aspect of Wigram Skies to commercial operators, who paid out $\$ 169$ million in wages - and the traditional Māori economy, where comprehensive communal employment and the associated wellbeing was a core component. ${ }^{62}$

The separation between the commercial and the cultural only serves to emphasise that Ngāi Tahu are not operating in a Māori economy, that they have essentially been forced to create an entity that, as Tipene O'Regan notes, in its "purpose and consequently, governance, is little different in structure and requirements from the corporately owned assets in the wider economy." That is, an entity that focuses on profit at the expense of the deeper values that guided and gave purpose to the traditional Māori economy. ${ }^{63}$ As well as being a practical response to the neoliberal economy the tribe faced during the settlement process, the creation of the Holdings Corporation can also be seen as the result of the internalised colonial narrative, which portrays Māori as "uneconomic"-such that the economic components of contemporary tribal operations are often kept at arm's length from "culture." 64 The Holdings Corporation emerges out of the undeniable fact that Ngāi Tahu are operating within both economically and culturally alien institutions - it was the best solution both practically and psychologically.

TRONT cannot prevent leakage, as it has limited institutional power beyond the tribe. And if it is to generate the profits required to continue operating the beneficial programmes, the Holdings Corporation must operate in a fashion similar to its competitors within the wider settler economy, meaning that there will inevitably be leakage. The wealth generated within the economy built by Ngāi Tahu suffers immediate and enduring leakage as there is no institutional framework in place to ensure that the tribe is able to continue to generate income from the initial outlay. This is not a criticism of the Holdings Corporation; it simply throws a light on the limitations of operating within the settler economy. It also provides a perspective on what is required for a Māori economy. The reason we do not have a tribal economy is because there are no Māori institutions to control or adjudicate Māori economic interests, and leakage is a symptom of this lack of control.

\section{What Might a Māori Economy Look Like?}

Given the above, we can begin to understand what a genuine Māori economy might look like. The need to explore this is not just academic, but rather could serve to ensure that the wealth of today will not have the same future as the wealth of the past: for the settlements of the recent past, when viewed through a deeper historical lens, take on a dangerously similar composition. To that end, this article argues that the fundamentals of any tribal economy must include:

- Political institutions that provide strong governance over tribal assets, such as a rūnanga model that has clearly defined powers that position it as an effective adjudicator and regulator of rights and exchange, across both internal and, to some degree, external affairs. Rūnanga need to be able to raise tax, through rates and an internal (Māori economy) GST.

- Legal institutions, including a tribal title that replaces Crown title for Māori /iwi land. 
Such institutions would need to respect communal and individual property rights, to provide balance between traditional property rights and contemporary economic needs, and to have the capacity to enforce and regulate business and financial contracts upon Māori /tribal land.

- Economic institutions that encourage internal economic exchange within and between tribes that provide for both social and economic outcomes, including the implementation of a non-cash method of exchange built on traditional reciprocal mechanisms and the creation of tribally-owned firms that enable collective and individual gains.

The key suggestion here is the political empowerment of the rūnanga, as most of the other institutions flow from this enhanced autonomy. To create a genuine Māori economy requires rūnanga to have similar institutional controls to those imagined by Grey and his contemporaries. This brings up issues of sovereignty, which is certainly a contentious area that would require much finessing. It would need to be explained that the powers granted to the rūnanga would not be very different from those of other local authorities, such as regional and city councils, that form the second tier of political authority within New Zealand; theoretically such powers would thus not cause any significant new problems with respect to the hierarchy of sovereignty within the country, as the Crown would remain sovereign. Furthermore, there are international examples that show that empowering indigenous people in this way is beneficial for both them and the wider economy, such as the development of urban reserves by First Nations in Canada. ${ }^{65}$ This aligns with a wider body of scholarship showing that indigenous economic development is more likely to succeed if it is conducted within culturally-matched institutions. ${ }^{66}$

Of these suggestions, the ones that differ most from the current framework of settler institutions are those concerning economic institutions. These are the least constrained by the need for increased political power, as they are already largely within the power of the tribes to create. Specifically, if TRONT wished to, it could create and regulate a non-cash system of exchange between tribal members, though without the political power over taxation this barter system would still need to operate within the New Zealand tax regime. Also, TRONT could change the Holdings Corporation mandate so that it also focused on employing Ngāi Tahu tribal members in construction on future projects, reducing the leakage.

\section{Conclusion}

Looking deeper into "the story" provides insight into what has been and what could be, and by doing so we are able to place Māori impoverishment and empowerment in context. This article builds on Banner's claim that Māori were "conquered by contract," by arguing that too often we concentrate on the small amount of land that Māori had been reserved as the reason for poverty among our people. This is misleading. Even if Māori had been allocated twice the amount of land, poverty would still have been the outcome, because the economy was scripted to suit the needs of the settlers. The fundamentals of any economy - the title to land, and the capacity to regulate commercial activities, tax and establish institutions to enforce laws and bylaws - are all part of a matrix that underpins that economy. Unless these fundamentals are controlled and defined by Māori, we will always fit within the settler state economy. Talk of a $\$ 50$ billion Māori economy is false. Even the current tribal corporations, Trusts, rūnanga and incorporations, which account for 30 percent of that $\$ 50$ billion, all operate within a script crafted by the settler state long ago. The Crown has title to our land, and regulates supply and demand, and in the end we always render unto Caesar what is his. There is no Māori economy, 
because, just as with our water, we do not control the dollar or the land the water flows upon.

Can there be a Māori economy? The question is fundamentally a political rather than a financial or economic one. Our surmise is that a Māori or tribal economy needs to be built upon the same foundations that underpin any other economy: strong politico-legal institutions that deliver the power to regulate and enforce laws and bylaws; the power to raise tax and revenue; tribal title to tribal properties; and the creation of economic institutions that encourage internal trade and enable both social and economic benefits. This would require a radical change in the political landscape, and while this may seem unlikely at this juncture, one insight that can be drawn from the analysis of stories is that we can expect future plot twists. If the tribal corporations can overwhelmingly prove that their financial operations are able to directly generate economic prosperity amongst both their members and the wider economy, alongside being individually profitable, then they may be able to shift the narrative. That is to say that Māori may need to utilise their own institutions to change the script, showing that culturally-matched institutions can benefit both Māori and the rest of New Zealand.

\footnotetext{
${ }^{1}$ Lorenzo Veracini, Settler Colonialism: A Theoretical Overview (Houndmills, Basingstoke: Palgrave Macmillan, 2010), 6.

${ }^{2}$ Veracini, Settler Colonialism, 6.

${ }^{3}$ Patrick Wolfe, "Settler Colonialism and the Elimination of the Native," Journal of Genocide Research 8, no. 4 (2006): 388.

${ }^{4}$ Patrick Wolfe, Settler Colonialism and the Transformation of Anthropology: The Politics and

Poetics of an Ethnographic Event (London, New York: Cassell, 1999), 2.

${ }^{5}$ John Reid, Matthew Rout, Te Maire Tau, and Cherryl Smith. The Colonising Environment: An Aetiology of the Trauma of Settler Colonisation and Land Alienation on Ngāi Tahu Whānau (Christchurch: Ngāi Tahu Research Centre, 2017).

${ }^{6}$ Scott L. Morgensen, "The Biopolitics of Settler Colonialism: Right Here, Right Now," Settler Colonial Studies 1, no. 1 (2011): 57.

${ }^{7}$ Paul Krugman, “How Did Economists Get It So Wrong?” New York Times Magazine, 2 September 2009. https://www.nytimes.com/2009/09/06/magazine/06Economic-t.html

${ }^{8}$ Mark Granovetter, "Economic Action and Social Structure: The Problem of Embeddedness," American Journal of Sociology 91, no. 3 (1985): 483.

${ }^{9}$ Thorstein Veblen, "Why Is Economics Not an Evolutionary Science?" The Quarterly Journal of Economics 12, no. 4 (1898): 389.

${ }^{10}$ Karl Polanyi, The Great Transformation (New York: Farrar \& Rinehart, Inc., 1944).

${ }^{11}$ Douglass C. North, Institutions, Institutional Change, and Economic Performance (Cambridge: Cambridge University Press, 1990), 3.

${ }^{12}$ E. A. Brett, "Institutional Theory and Social Change in Uganda," in The New Institutional Economics and Third World Development, ed. John Harriss, Janet Hunter, and Colin M. Lewis (London: Routledge, 1995).

${ }^{13}$ Brett, "Institutional Theory and Social Change in Uganda."

${ }^{14}$ Oliver E. Williamson, "The New Institutional Economics: Taking Stock, Looking Ahead," Journal of Economic Literature 38, no. 3 (2000).

${ }^{15}$ Paul L. Joskow. "Introduction to New Institutional Economics: A Report Card," in New Institutional Economics: A Guidebook, ed. Eric Brousseau and Jean-Michel Glachant (Cambridge, UK: Cambridge University Press, 2008).

${ }^{16}$ Brett, "Institutional Theory and Social Change in Uganda," 207.

${ }^{17}$ Stuart Banner, "Conquest by Contract: Wealth Transfer and Land Market Structure in Colonial New Zealand," Law and Society Review 34, no. 1 (2000): 47-48.
} 
${ }^{18}$ Banner, "Conquest by Contract," 48.

${ }^{19}$ Banner, "Conquest by Contract," 49.

${ }^{20}$ Banner, "Conquest by Contract," 92.

${ }^{21}$ Appendices to the Journals of the House of Representatives (AJHR) 1860, E-1, 4.

${ }^{22}$ Thomas Gore Browne, "Memorandum, 28 April 1857," AJHR (1858), E-5, 9; Hazel Petrie, Chiefs

of Industry: Māori Tribal Enterprise in Early Colonial New Zealand (Auckland University Press, 2013).

${ }^{23}$ Petrie, Chiefs of Industry, 162.

${ }^{24}$ Alan Ward, "A Report on the Historical Evidence: The Ngai Tahu Claim Wai 27," Commissioned by the Waitangi Tribunal (1989), T-1, 306.

${ }^{25}$ Ward, "A Report on the Historical Evidence: The Ngai Tahu Claim," 326.

${ }^{26}$ John Reid and Matthew Rout, "Māori Tribal Economy: Rethinking the Original Economic

Institutions," in Unlocking the Wealth of Indian Nations, ed. Terry L. Anderson (Lanham, Maryland: Lexington Books, 2016), 84-106.

${ }^{27}$ Hirini Moko Mead, Tikanga Māori: Living By Māori Values (Wellington: Huia Publishers, 2016); Petrie, Chiefs of Industry.

${ }^{28}$ Polanyi, The Great Transformation, 44.

${ }^{29}$ Nuno Miguel Cardoso Machado, "Karl Polanyi and the New Economic Sociology: Notes on the Concept of (Dis) Embeddedness," RCCS Annual Review 3 (2011):

https://papers.ssrn.com/sol3/papers.cfm?abstract_id=2307197

${ }^{30}$ Quoted in Bryan D. Gilling, "Engine of Destruction - An Introduction to the History of the Maori Land Court." Victoria University Wellington Law Review 24 (1994): 115-16.

${ }^{31}$ David V. Williams, Te Kooti Tango Whenua: The Native Land Court 1864-1909 (Wellington: Huia Publishers, 1999), 5.

${ }^{32}$ Polanyi, The Great Transformation, 187-88.

${ }^{33}$ Williams, Te Kooti Tango Whenua.

${ }^{34}$ Ward, "A Report on the Historical Evidence: The Ngai Tahu Claim," T1, 404. Hazel Petrie refers to this calculation as well, but also outlined the view of C. W. Richmond, Colonial Treasurer, that this ratio was overestimated. Nonetheless, Native Secretary Donald McLean supported Browne's estimate. Hazel Petrie "Colonisation and the Involution of the Maori Economy" (paper presented at Session 24 of the Thirteenth World Congress of Economic History, Buenos Aires (2002).

${ }^{35}$ Vincent O'Malley, The Great War for New Zealand: Waikato 1800-2000 (Wellington: BWB, 2016); Petrie, Chiefs of Industry; P. Toft, Modern Mãori Enterprise: A Study of Economic Adaptation (Masters thesis, Auckland, University of Auckland, 1984).

${ }^{36}$ Wolfe, 2006.

${ }^{37}$ Richard S. Hill, State Authority, Indigenous Autonomy: Crown-Maori Relations in New Zealand/Aotearoa 1900-1950 (Wellington: Victoria University Press, 2004), 15.

${ }^{38}$ George Grey, "Minute by Governor Sir George Grey on the subject of his His Excellency's Plan of Native Government," AJHR (1862), E-2, 12.

${ }^{39}$ Richard S. Hill, Policing the Colonial Frontier: The Theory and Practice of Coercive Social and Racial Control in New Zealand, 1767-1867 (Wellington: V. R. Ward, Government Printer, 1986): 813840. Hill sees the New Institutions primarily as instruments of indirect control of Maori by the Crown. ${ }^{40}$ Sewell, quoted in M.P.K. Sorrenson, "Land purchase methods and Their Effect on Maori Population, 1865-1901," The Journal of the Polynesian Society 65, no. 3 (1956): 189.

${ }^{41}$ Māori of 1860 were not the same as when Cook arrived in 1769. The arrival of sealers and whalers, and the increasing trade with New South Wales, had utterly changed the nature of land tenure among the tribes and in particular those that had been trading on the coastlines. To say that customary title was non-commercial in 1860 would be to ignore the commercial activities of Māori. Conversely, while some tribes may very well have developed potato fields on a communal base to trade, we also know that among other tribes the notion of communal agricultural fields simply did not occur.

${ }^{42}$ James Edward FitzGerald, "Native Lands Bill," NZPD (1862): 628.

${ }^{43}$ William Fox, "Further Minute by Ministers in Reference to His Excellency's Plan," AJHR (1862), $\mathrm{E}-2,15$. 
${ }^{44}$ Keith Sinclair and Raewyn Dalziel, A History of New Zealand (Auckland: Penguin, 1980), 136; Vincent O'Malley, "English Law and the Māori Response: A Case Study from the Runanga System in Northland, 1861-65," The Journal of the Polynesian Society 116, no. 1, (2007): 7.

${ }^{45}$ Quoted in O'Malley, "English Law and the Māori Response," 15.

${ }^{46}$ Hill, State Authority, Indigenous Autonomy, 32.

${ }^{47}$ George Grey, "Minute by Governor, Sir George Grey," AJHR (1862), E-2, 12. The passage missed in the cited text refers to Grey's intention of limiting the sale of land from Māori to one farm per purchaser. The purchaser was to occupy the land for three years with only six weeks absence allowed. The intention was to stop land speculators purchasing and quickly onselling. which would eventually lead to an increase in prices.

${ }^{48}$ Grey, "Minute by Governor, Sir George Grey," 13-14.

${ }^{49}$ O’Malley, "English Law and the Māori Response," 16.

${ }^{50}$ James O. Gump, "The Imperialism of Cultural Assimilation: Sir George Grey's Encounter with the Maori and the Xhosa, 1845-1868," Journal of World History 9, no. 1 (1998).

${ }^{51}$ Henry Sewell, The New Zealand Native Rebellion, Letter to Lord Lyttelton (Dunedin: Hocken Library, 1864), 9.

${ }^{52}$ Gump, "The Imperialism of Cultural Assimilation.

${ }^{53}$ Sewell, The New Zealand Native Rebellion," 7.

${ }^{54}$ Sewell, The New Zealand Native Rebellion," 10.

${ }^{55}$ Thomas Gore Browne, "Memorandum, 28 April 1857," AJHR (1858), E-5, 9.

${ }^{56}$ Browne, "Memorandum," 9.

${ }^{57}$ Richard S. Hill, Maori and the State: Crown-Maori Relations in New Zealand/Aotearoa, 19502000 (Wellington: Victoria University Press, 2010).

${ }^{58}$ Chapman Tripp, Te ao Māori-Trends and Insights (Auckland: Chapman Tripp, 2017).

${ }^{59}$ Ngāi Tahu Research Centre, Tribal Economies Leakage Brochure (Christchurch: Ngāi Tahu Research Centre, 2017).

${ }^{60}$ Ngāi Tahu Research Centre, Tribal Economies Leakage Brochure.

${ }^{61}$ Reid and Rout, "Māori Tribal Economy."

${ }^{62}$ Ngāi Tahu Research Centre, Tribal Economies Leakage Brochure; Reid and Rout, "Māori Tribal Economy."

${ }^{63}$ Te Rūnanga o Ngāi Tahu, Charter of Te Rūnanga o Ngāi Tahu (Christchurch: Te Rūnanga o Ngāi Tahu, 2012), 33.

${ }^{64}$ Reid and Rout, "Māori Tribal Economy."

${ }^{65}$ Holli Poholka, "First Nation Successes: Developing Urban Reserves in Canada" (Masters dissertation, Queen's University, Kingston, Ontario, 2016).

${ }^{66}$ Stephen Cornell and Joseph P. Kalt, "Where does Economic Development really come from?

Constitutional Rule among the Contemporary Sioux and Apache," Economic Inquiry 33 (1995): 40226; Stephen Cornell and Joseph P. Kalt, "Where's the Glue? Institutional and Cultural Foundations of American Indian Economic Development," The Journal of Socio-Economics 29, no. 5(2000): 443-70. 